\title{
Complications and outcomes of 890 living liver donor hepatectomies at a single center: risks of saving loved one's life
}

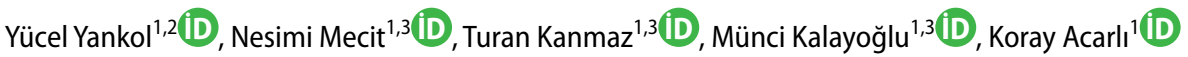 \\ ${ }^{1}$ Organ Transplantation Center, Memorial Sisli Hospital, Istanbul, Turkey \\ ${ }^{2}$ Department of Surgery Division of Transplantation, University of Wisconsin, Madison, WI, United States of America \\ ${ }^{3}$ Organ Transplantation Center, Koc University School of Medicine Hospital, Istanbul, Turkey
}

\begin{abstract}
Objective: Living liver donor surgery is a major surgical procedure applied to healthy people with mortality and morbidity risks and does not provide any direct therapeutic advantage to the donor. We retrospectively analyzed the postoperative complication of our living liver donors to figure out the risks of donation.
\end{abstract}

Material and Methods: Between November, 2006 and December, 2018, a total of 939 living liver donor hepatectomies were performed with no mortality to the living-related donors. Eight hundred and ninety donors with a minimum 1-year follow-up were analyzed retrospectively.

Results: Of the 890 donors, 519 (58.3\%) were males and 371 (41.7\%) were females. Mean age was 35 years (18-64) and mean body mass index was 25.7 $\mathrm{kg} / \mathrm{m}^{2}$ (17.7-40). Right donor hepatectomy was performed to $601(67.5 \%)$, left donor hepatectomy to 28 (3.2\%) and left lateral sector hepatectomy to 261 (29.3\%) of the donors. Of the 890 donors, 174 (19.5\%) donors experienced a total of 204 early and late complications including life- threatening and nearly life- threatening complications in $26(2.9 \%)$ of them. Intraoperative complication occurred in 4 (0.5\%) donors. Right donors hepatectomy complication rate (23.3\%) was higher than left donor (14.3\%) and left lateral sector donor hepatectomy (11.5\%).

Conclusion: All donor candidates should be well-informed not only on the details of early and late complications of living liver donation, also possible outcomes of the recipient. In addition to detailed physical evaluation, preoperative psychosocial evaluation is also mandatory. Comprehensive donor evaluation, surgical experience, surgical technique, close postoperative follow-up and establishing a good dialog with the donor allows better outcomes.

Keywords: Living donor hepatectomy, complications, outcomes, living liver donor transplantation, life-threatening complications

Cite this article as: Yankol Y, Mecit N, Kanmaz T, Kalayoğlu M, Acarlı K. Complications and outcomes of 890 living liver donor hepatectomies at a single center: risks of saving loved one's life. Turk J Surg 2020; 36 (2): 192-201.

Corresponding Author

Yücel Yankol

E-mail: yyankol@yahoo.com

Received: 18.11.2019

Accepted: 27.11.2019

Available Online Date: 08.06.2020

O Copyright 2020 by Turkish Surgical Society Available online at www.turkjsurg.com

DOI: $10.5578 /$ turkjsurg. 4548

\section{INTRODUCTION}

Liver transplantation (LT) is currently the only lifesaving and definitive treatment for end-stage liver disease, acute liver failure, some metabolic diseases and some liver tumors. Despite remarkable recipient outcomes, a significant number of people die on the waiting list. One strategy used to counter-balance organ shortage has been the utilization of living donor liver transplantation (LDLT), which is the only option in a region with insufficient deceased donor support. Studies consistently demonstrate that LDLT is equivalent to deceased donor liver transplantation (DDLT) in terms of patient and allograft survival (1). Although LDLT was initially considered in 1969 (2), the first real attempt took place in 1988 (3,4). Over the past two decades, while attempts continued in Western countries, significant progress was achieved in Asia, where religious and cultural beliefs do not allow deceased donation to significantly contribute to the donor pool (5).

Although LDLT is a potentially life-saving operation for the recipient, with similar outcomes to DDLT, living liver donor hepatectomy (LLDH) is a major surgical procedure with morbidity and mortality risks, which is applied to healthy people. In addition, donor surgery does not provide any direct therapeutic advantage to the donor. The donor undertakes these risks to save the life of a loved one. This report retrospectively analyzed postoperative donor complications and outcomes to evaluate the risks of living liver donation at an experienced center in a region with insufficient deceased donor support. 


\section{MATERIAL and METHODS}

Between August 2006 and November 2018, 1,126 LTs (766 adult, 340 pediatric) were performed at a single center, 939 from living related donors and 187 from deceased donors. The first LDLT was performed in November 2006. During this period, 939 LLDH patients were discharged with no mortality. Of the 939 living related donor-recipient pairs, 126 (13.4\%) were from 20 different foreign countries. The first $890 \mathrm{LLDH}$ cases, performed between November 2006 and December 2017 with a minimum 1-year follow-up, were retrospectively analyzed (Figure 1). Data were collected including donor age, gender, body mass index (BMI), graft type, operation time, length of hospital stay and donor complications. Complications were scored using the modified Clavien classification of surgical complications and adapted donor morbidity classifications (6-8). SPSS version 13.0 (SPSS, Inc., Chicago, IL, USA) was used for the analysis.

\section{Donor Evaluation and Selection}

Requirements for donor candidacy included age $>18$ years and good health condition with no comorbidities. By the Turkish Health Ministry Organ Donation Ethics Committee policy, potential donors are required to be first-degree relatives (parents, children), second-degree relatives (grandparents, siblings, grandchildren), or third- or fourth-degree relatives (uncles, aunts, nephews, cousins) of the intended recipient. Spouses and other Ethics Committee-approved related patients are also considered as potential donors (Table 1). This standard also applies to donor and recipient candidates from foreign countries, in which case donor evaluation is undertaken only after a formal document has been received from their government proving close consanguinity of the donor and recipient. In addition, all formal documents re- quire approval from their Embassy or Consulate in Turkey. During the evaluation in this study, candidates were informed about all LLDH procedures, risks of surgical complications, and expected recipient outcomes with the family members. In addition, they were informed that they could decline continuation of the evaluation at any time. Most LLDH candidates had a body mass index $(\mathrm{BMI})<30$, but in rare emergency cases, donors with $\mathrm{BMI}>30$ were also considered. All candidates underwent extensive preoperative work-up including blood type, extensive biochemistry, coagulation, urine, hepatitis A, B, C and D virus, human immunodeficiency virus, Epstein-Barr virus, cytomegalovirus, pregnancy (for females), venereal disease, and factor 2 and factor 5 Leiden mutation tests. Donor candidates $>40$ years of age underwent echocardiography and cardiology evaluation, and if a smoker, respiratory function testing and pulmonary examination were performed. All donor evaluations included hepatology and psychiatric examinations. In addition, thoracic and abdominal computed tomography (CT) and electrocardiography were performed in all candidates. CT assessed liver volume, parenchyma and vascular structures. The biliary system was evaluated by magnetic resonance cholangiopancreatography (MRCP). Donors with remnant liver volume $>30 \%$ and remnant liver weight:donor weight ratio $>0.5 \%$ were considered candidates for donation. Most were approved if the graft weight:recipient weight ratio (GWRBR) was > $1 \%$. If the GWRWR was $>0.8 \%$, donation was only considered in emergencies and was rarely approved. Donor livers with $>10 \%$ steatosis were not accepted, but a diet and exercise program was suggested, with re-evaluation and reconsideration possible. In rare cases, liver biopsy was performed to determine the true steatosis stage.

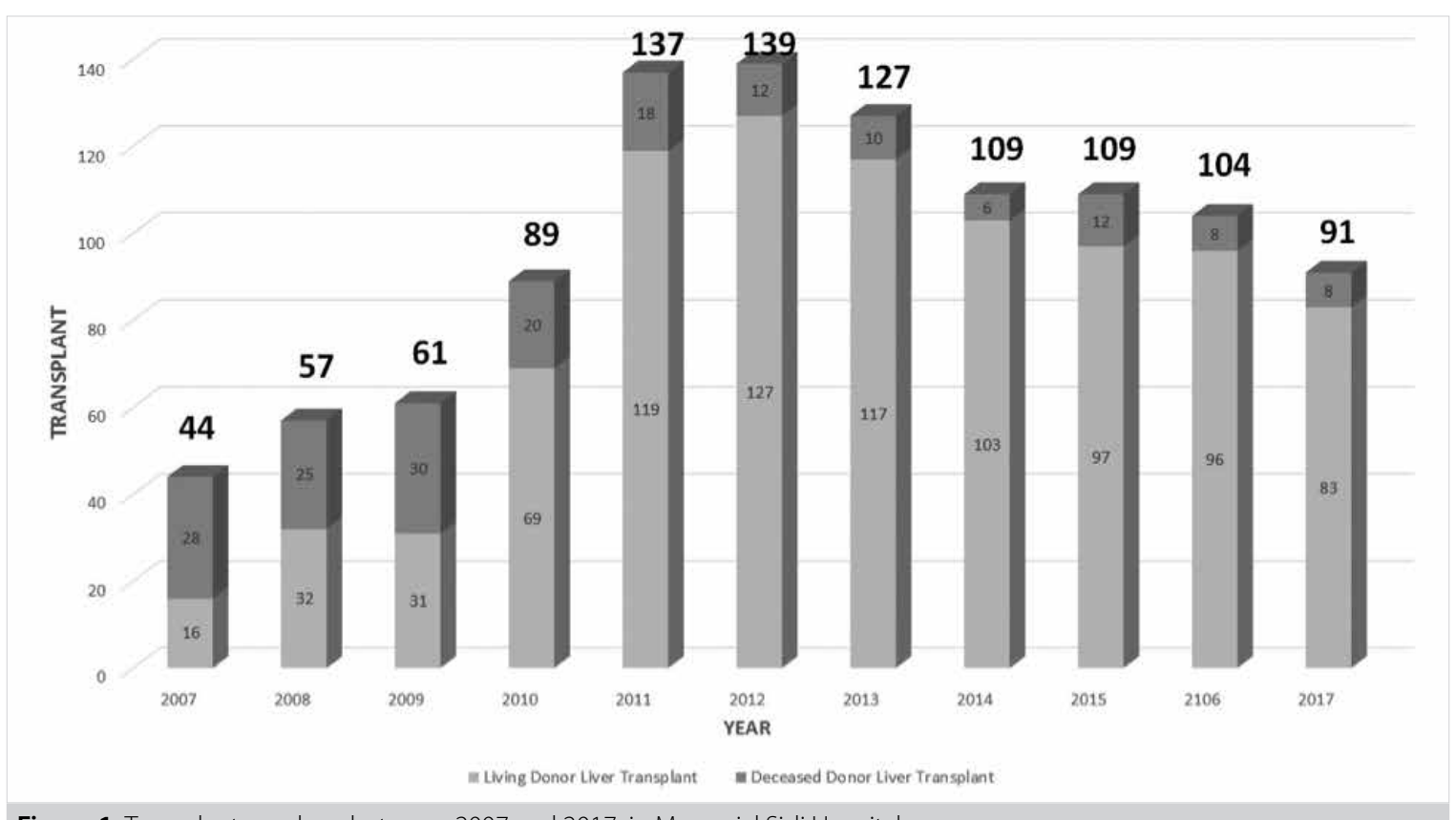

Figure 1. Transplant numbers between 2007 and 2017 in Memorial Sisli Hospital. 
Table 1. Donor demographics

\begin{tabular}{|c|c|}
\hline Demographic features & \\
\hline Mean age (years) & 35 (range 18-64) \\
\hline $\operatorname{Sex}(n, \%)$ & \\
\hline Male & $519(58.3 \%)$ \\
\hline Female & $371(41.7 \%)$ \\
\hline Mean BMI $\left(\mathrm{kg} / \mathrm{m}^{2}\right)$ & 25.7 (range 17.7-40) \\
\hline Relationship with recipient (n, \%) & \\
\hline First grade relatives & $526(59 \%)$ \\
\hline Second grade relatives & $143(16 \%)$ \\
\hline Third \& fourth grade relatives & $144(16 \%)$ \\
\hline Ethical committee approved & $77(9 \%)$ \\
\hline Donor hepatectomy type (n, \%) & \\
\hline Right hepatectomy & $601(67.5 \%)$ \\
\hline Left hepatectomy & $28(3.2 \%)$ \\
\hline Left lateral sector hepatectomy & $261(29.3 \%)$ \\
\hline Mean operation time (hours/minutes & \\
\hline Right hepatectomy & $5 \mathrm{~h}$ and $9 \mathrm{~m}$ \\
\hline Left hepatectomy & $6 \mathrm{~h}$ and $12 \mathrm{~m}$ \\
\hline Left lateral sector hepatectomy & $4 \mathrm{~h}$ and $13 \mathrm{~m}$ \\
\hline Medium hospital stay (days) & 7 (range 5-58) \\
\hline
\end{tabular}

\section{Surgical Procedure and Postoperative Care}

All donors were admitted to the hospital one day prior to surgery and underwent examination by the surgical team. Preoperative signed informed consent was obtained in call cases. Two hours prior to surgery, low molecular weight heparin $(\mathrm{LMWH})(\mathrm{Clexane}$ 4000 IU/0.4 mL or Clexane 6000IU/0.6 mL sc injection; Sanofi Aventis Pharma, Istanbul, Turkey) was administered to all donors according to body weight for thrombosis prophylaxis and was continued for one week postoperatively. Most donor hepatectomies (96\%) were performed by two surgeons (K.A. and Y.Y.); $4 \%$ was performed by other team members or clinical fellows. All hepatectomies were performed under the supervision of an experienced transplant and hepatopancreaticobiliary surgeon.

In most cases, a median J-shaped incision was made. In some left lateral sector donors, a small bilateral subcostal or upper median incision was made. Exploration of the liver and abdominal organs was performed in all cases. If exploration findings were normal, the right or left lobe of the liver was mobilized according to graft type. The right or left hepatic vein was isolated according to graft type. All other hepatic veins larger than $5 \mathrm{~mm}$ which drained directly to the inferior vena cava were protected. The right or left hepatic artery and right or left portal vein were isolated, and cholecystectomy was performed. Following cholecystectomy, cholangiography was performed through the cystic duct stump to evaluate the biliary system anatomy. In most cases, the right bile duct was cut before parenchymal division, and the left bile duct was cut after parenchymal division. In some cases, the right bile duct was cut after parenchymal division. Parenchymal dissections and divisions were performed using Cavitron Ultrasonic Aspirator (CUSA System 200 Macrodissector; Cavitron Surgical System, Stamford, CT, USA) and bipolar electrocautery. The Pringle maneuver was never used during parenchymal division, and central venous pressure was held below 5 $\mathrm{cm} \mathrm{H2O}$. A hanging maneuver was used in all cases. The middle hepatic vein was left with the remnant or taken with the graft according to the volumes and branches of the middle hepatic vein. After completing parenchymal division, the graft was removed by transecting the hepatic artery, portal vein and hepatic vein branches of the graft. The hepatic artery stump in the donor was tied with 4/0 silk sutures, and the hepatic vein stump was closed with 4/0 prolene. The portal vein stump was closed with 6/0 prolene and the bile duct stump was closed with 6/0 polydioxanon (PDS) sutures. The biliary system and cut surfaces were always checked with cholangiography and air test after the closure of the bile duct stump. The remnant left liver lobe was always fixed to the diaphragm after right donor hepatectomy. A silastic drainage tube was inserted in all cases, and surgery was completed with closure of the abdomen.

Following extubation in the operating room, all donors were taken to the intensive care unit and monitored closely for one day. Liver function tests were performed every day for one week and prophylactic antibiotics were given for the first two days. The nasogastric tube was removed on postoperative day 1 and oral feeding started on postoperative day 2 for most of 
the donors. Urinary catheter was removed on postoperative day 1 , and central venous catheter was removed on postoperative day 4. In order to reduce postoperative atelectasis and deep vein thrombosis (DVT), early mobilization with preoperative embolism stockings and spirometer breathing exercises were started. An abdominal ultrasound was performed on donors with unexpected high liver enzymes, high International Normalized Radio (INR), bile leak or abdominal pain. The silastic drainage tube was removed at uncomplicated cases between postoperative day 3 and 6 according to the amount of drainage and findings. Post-discharge, all donors were followed in clinic with liver function tests and physical examination at 2 weeks and 1, 2, 3, 6, 9 and 12 months after surgery. After one year, donors were instructed to contact clinic if they had any problems or complications related to surgery.

Donors always underwent Doppler ultrasound for ALT > 800 $(U / L)$ or $I N R>2.5$. We always perform MRCP in donors whose alkaline phosphatase (ALP), GGT and total bilirubin do not start to normalize within 10 days after surgery. We support the donor liver after the procedure with fresh frozen plasma if INR is $>2$ and with human albumin if albumin is $<3 \mathrm{~g} / \mathrm{dL}$. During the first 4 days postoperatively, we support the liver with high-glucose solutions. We give prophylactic antibiotics to all donors during the first postoperative 48 hours. If there are any infection findings or any postoperative complications that might increase the risk of infection, we continue with antibiotic treatment.

\section{RESULTS}

Of the 890 donors, 519 (58.3\%) were males and 371 (41.7\%) females. Mean age was 35 years (range 18-64), and 27 (3\%) donors were older than 55, including 9 donors (1\%) at > 60 years of age. Mean donor BMI was 25.7 (range 17.7-40), 95 donors had $\mathrm{BMI}>30$, and 12 donors had $>35$. Of the 890 donors, 63 (7\%) were spouses, 463 (52\%) were first-degree relatives (parents and children), 143 (16\%) were second-degree relatives (grandparents, siblings and grandchildren), 144 (16\%) were third- or fourth-degree relatives (uncles, aunts, nephews and cousins), and 77 (9\%) were other ethics-committee approved related donors (Table 1). Of the 890 donors, 601 (67.5\%) underwent right lobe donor hepatectomy (RLH), 261 (29.3\%) underwent left lateral sector hepatectomy (LLH) and 28 (3.2\%) underwent left lobe donor hepatectomy (LDH). Mean operation time for RLH was 5 hours and 9 minutes, for LDH was 6 hours and 12 minutes and for LLH was 4 hours and 13 minutes. Median hospital stay was 7 days (range 5-58 days) (Table 1).

No donor surgery was aborted intraoperatively due to bile duct anatomy or vascular structures. One donor surgery was aborted intraoperatively due to liver findings. In that case, all preoperative testings was normal with no suspicion of liver disease, but during exploration the liver was found to be abnormal. Liver biopsy was performed with the finding of Grade 1-2 fibrosis, and recipient surgery was canceled prior to its start. This donor was referred to the Hepatology Department for follow-up. Another donor surgery was aborted due to cardiac arrest and death of the recipient on the operating table. At that point, half of the donor parenchymal division was finished and the right bile duct was already cut. The donor surgery did not go forward and Roux-en-Y right hepaticojejunostomy was performed without donor hepatectomy. No complication occurred in this donor candidate during the follow-up period.

In two donors, following right donor hepatectomy, Roux-en-Y left hepaticojejunostomy was performed during donor surgery, which was planned preoperatively in one case due to the diagnosis of Type 1a choledochal cysts during the evaluation. In that patient, following right donor hepatectomy, common bile duct resection and Roux-en-Y left hepaticojejunostomy were performed. In the second donor, a bile duct stricture was noted on perioperative control cholangiography after closing the bile duct stump, and Roux-en-Y left hepaticojejunostomy was performed. No complication occurred in this donor during the follow-up period. In one donor, a bile leak was noted after closure of the bile duct stump. Suturing the leak would be unsafe, so a T-tube was placed in the common bile duct in that case. No additional complications occurred after the T-tube was removed. In one donor, the vascular staff loosened the right hepatic vein during the procedure and emergency thoracotomy was required to stop the bleeding; subsequently, a serious pulmonary infection developed, necessitating a > 1-month ICU stay. In one case, early portal vein thrombosis (PVT) occurred due to the closure technique, which was treated surgically within 6 hours without a postoperative problem. Our intraoperative complication rate was $0.5 \%$ (2 biliary, 1 early PVT, 1 hepatic vein bleeding).

Of the 890 donors, 174 (19.5\%) experienced postoperative complications, including life threatening and nearly life-threatening complications in 26 (2.9\%). Surgical treatment was required in 36 donors (4\%) due to early or late complications. A total of 204 early and late complications developed in these 174 patients according to the Clavien adapted donor morbidity classification $(7,8)$ (Table 2). Twenty-one donors developed two complications, and four donors developed three or more complications. There were no donor deaths due to LLDH in this series. One donor died years later, following a motor vehicle collision and one donor underwent liver transplantation from a deceased donor due to a new diagnosis of benign recurrent intrahepatic cholestasis (BRIC) 14 months after LLDH. Of note, the recipient of this donor, who had the same diagnosis prior to transplantation, underwent re-transplantation from a deceased donor one year later. One donor was diagnosed with leukemia years after LLDH and underwent treatment. In three donors, psychiatric medical treatments were required for a short time period due to anxiety after LLDH. All of these donors had experienced Grade 3 or 4 complications. 
Table 2. Complications according to adapted Clavien classification (204 complications in 174 donors)

\begin{tabular}{|c|c|c|c|}
\hline \multirow{2}{*}{\begin{tabular}{|l|} 
Grade \\
Grade 1
\end{tabular}} & \multirow{2}{*}{\begin{tabular}{|l|} 
Number of the patients and \% \\
$112(12.6 \%)$
\end{tabular}} & \multicolumn{2}{|l|}{ Complications and number of the patients } \\
\hline & & $\begin{array}{l}\text { Wound problems (bedside and medical treatment) } \\
\text { Vomiting (remarkable-medical treatment) } \\
\text { Ascites \& Pleural effusion (medical treatment) } \\
\text { Bile leak (spontaneously resolved) } \\
\text { Pain (remarkable-medical treatment) } \\
\text { Sub-ileus (Follow-up) }\end{array}$ & $\begin{array}{lr}: & 49 \\
: & 23 \\
: & 17 \\
: & 8 \\
: & 8 \\
: & 7\end{array}$ \\
\hline Grade 2 & $15(1.7 \%)$ & $\begin{array}{ll}\text { Pulmonary embolism (minor-medical treatment) } \\
\text { Pneumonia \& atelectasis } & \text { (medical treatment) } \\
\text { Diarrhea } & \text { (medical treatment) } \\
\text { Urinary infection } & \text { (medical treatment) } \\
\text { Anxiety } & \text { (medical treatment) } \\
\text { Vertigo } & \text { (medical treatment) } \\
\text { Cardiac arrhythmia } & \text { (medical treatment) }\end{array}$ & $\begin{array}{l}: \\
: \\
: \\
: \\
: \\
: \\
:\end{array}$ \\
\hline $\begin{array}{r}\text { Grade } 3 \\
3 a \\
3 b\end{array}$ & $\begin{array}{l}70(7.8 \%) \\
35(3.9 \%) \\
35(3.9 \%)\end{array}$ & $\begin{array}{l}\begin{array}{l}\text { Pleural effusion \& abdominal collection } \\
\text { (percutaneous drainage) }\end{array} \\
\text { Gastric ulcer bleeding (endoscopic treatment) } \\
\text { Bile leak } \\
\quad \text { (percutaneous drainage only) } \\
\quad \text { (PTC-D \& ERCP-S) } \\
\quad \text { * (surgical treatment - hepaticojejunostomy) } \\
\quad \text { * (surgical treatment - surgical drainage ) } \\
\text { Biliary stricture } \\
\quad \text { (PTC-D \& ERCP-S) } \\
\text { * (surgical treatment - hepaticojejunostomy) } \\
\text { * Bleeding (surgical treatment and transfusion) } \\
\text { Incisional hernia (surgical treatment) } \\
\text { Wound problems (surgical treatment) } \\
\text { * Intestinal obstruction (surgical treatment) } \\
\text { * Intestinal perforation (surgical treatment) }\end{array}$ & 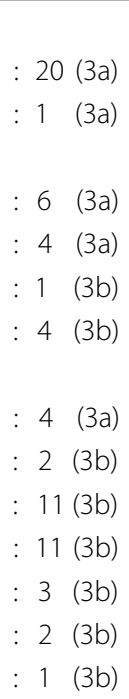 \\
\hline $\begin{array}{r}\text { Grade } 4 \\
4 a \\
4 b\end{array}$ & $7(0.8 \%)$ & 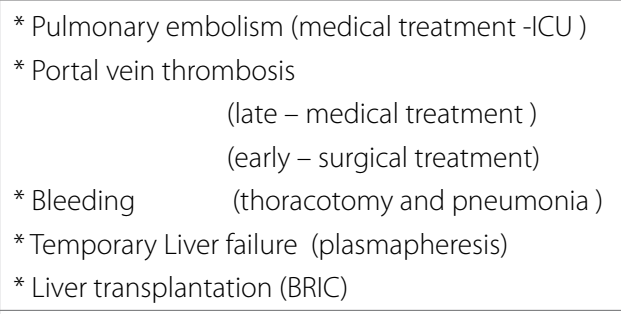 & 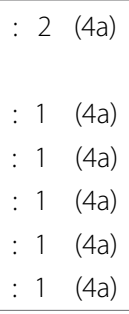 \\
\hline Grade 5 & - & - & \\
\hline $\begin{array}{l}\text { * life-threat } \\
\text { PTC-D: Perc } \\
\text { ERCP-S: End } \\
\text { BRIC: Benig }\end{array}$ & $\begin{array}{l}\text { nearly life- threatening complications } \\
\text { ss transhepatic cholangiogram and bilia } \\
\text { Retrograde Cholangio-Pancreatograph } \\
\text { ent intrahepatic cholestasis. }\end{array}$ & $\begin{array}{l}\text { in } 26 \text { donors - } 2.9 \%) \text {. } \\
\text { ry drainage. } \\
\text { y and stent replacement. }\end{array}$ & \\
\hline
\end{tabular}

Twelve (1.3\%) of our donors experienced perioperative bleeding. Early postoperative bleeding was noted by drain output in the other 11 of these donors. Twenty-one (2.4\%) of our donors experienced biliary complications, of which 8 were minimal bile leaks which resolved spontaneously in 3 to 20 days by following drain output only. In the other 13 (1.5\%) donors, 21 invasive procedures were performed to resolve the problems. In 6 donors, biliary stricture occurred, most following a bile leak ( $n=5$ ); two of these required treatment by hepaticojejunostomy.

One of our donors, aged 50, experienced temporary liver failure and underwent plasmapheresis during the first week after the procedure. This patient's total bilirubin level reached $19.0 \mathrm{mg} /$ $\mathrm{dL}$ and INR 1.7 during the first week after the procedure. This 
Table 3. Donor complication rates according to subgroups

\begin{tabular}{|l|c|c|}
\hline Donors subgroups & $\mathbf{n}$ (complication)/n (subgroup) & Complication \% \\
\hline All donors & $174 / 890$ & $19.5 \%$ \\
\hline Age $\geq 60$ & $2 / 9$ & $\mathbf{2 2 . 2} \%$ \\
Age $\geq 55$ and $<60$ & $3 / 16$ & $18.8 \%$ \\
\hline $\mathrm{BMl} \geq 35 \mathrm{~kg} / \mathrm{m}^{2}$ & $2 / 12$ & $16.5 \%$ \\
$\mathrm{BMl} \geq 30 \mathrm{~kg} / \mathrm{m}^{2}$ and $<35 \mathrm{~kg} / \mathrm{m}^{2}$ & $19 / 95$ & $20.0 \%$ \\
\hline Right donor hepatectomy & $140 / 601$ & $\mathbf{2 3 . 3} \%$ \\
Left donor hepatectomy & $4 / 28$ & $14.3 \%$ \\
Left lateral sector donor hepatectomy & $30 / 261$ & $11.5 \%$ \\
\hline
\end{tabular}

donor also experienced complications including minimal bile leak, wound infection and incisional hernia. In addition to this case, in other 17 donors, total bilirubin reached a level between 10 and $15 \mathrm{mg} / \mathrm{dL}$ and INR reached 1.5 to 2.0. In six of these patients, biliary complication was diagnosed and treated. In the other 11 donors, total bilirubin levels and all liver functions normalized within 7 to 20 days after the procedure, with the same complication rate (18.2\%).

In 43 donors, INR levels reached a level between 2 and 3; in 5 due to warfarin treatment (4 PE and 1 early PVT). In 38 donors, INR reached this level during the first one to four days postoperatively and normalized after support treatment. In 16 donors, alanine aminotransferase (ALT) reached a level over $1000 \mathrm{U} / \mathrm{L}$, and in 44 donors over $800 \mathrm{U} / \mathrm{L}$. Seven of the donors with ALT > $1000 \mathrm{U} / \mathrm{L}$ were left lateral sector donors who had a normal Doppler ultrasound. In our 45 donors, gamma-glutamyl transferase (GGT) reached a level over $1000 \mathrm{U} / \mathrm{L}$ and in 112 donors between 500 and $1000 \mathrm{U} / \mathrm{L}$. Only 11 of these donors were diagnosed with a biliary complication, and all normalized within 45 days postoperatively.

Donor complication rate was $22.2 \%$ in donors $>60$ years of age and $18.8 \%$ in donors 55 to 60 years of age. Donor complication rate was $16.7 \%$ in (1 donor complication was a wound infection and a second one was a PE requiring an ICU admission) donors with $\mathrm{BMI}>35 \mathrm{~kg} / \mathrm{m}^{2}(\mathrm{n}=12)$ and $20 \%$ in donors with BMI between 30 and 35 ( $n=95)$. In one case, a minor PE occurred. In our RLH donors, the complication rate was $23.3 \%$, which was higher than that for LDH (14.3\%) and LLH (11.5\%) (Table 3).

\section{DISCUSSION}

LDLT is the only alternative to DDLT in regions that do not have enough deceased donors (DD) to meet the needs of their waiting lists. LDLT has also become an alternative life-saving method that reduces patient waiting time and mortality on the waiting list in regions that do have good DD support. Although recipient outcomes after LDLT are similar to those after DDLT, donor safety is still the most important discussion, and LLDH carries a significant risk of morbidity and mortality for the otherwise healthy donor.
The incidence of morbidity and mortality after LLDH is not well known because reporting is not standardized and relies on single center, or in some countries, registry reports. Mortality rate has been reported to be $0.1 \%$ to $0.3 \%$ (9-11). Results of a worldwide survey conducted among 148 programs performing LDLT, with 71 (48\%) programs in 21 countries completing the survey, including 11,553 LLDH, has been published by Cheah $Y L$, et al. (12). According to this survey, donor mortality rate was $0.2 \%(23 / 11,553)$ with the majority of deaths occurring within 60 days of surgery, and all but four deaths were related to donation surgery. A data review of more than 300 articles, including nearly $6000 \mathrm{LLDH}$, has reported an overall mortality rate of $0.2 \%(10,13)$. Many single-center experiences with the same complication rate have been reported from Turkey and other countries $(8,9,14-19)$.We reported briefly our complications in the first 419 LLDH cases in a previous manuscript (20). Including these reported cases, in our first 939 living liver donors, no death occurred related to surgery or complications in our program. Our donor candidates were given an estimated mortality rate of $0.1 \%$ and $0.2 \%$.

The complication rate after LLDH varies widely in the literature, between 9 and 40\% (8,9,12,14-19,21,22). Among our donors, $19.5 \%$ experienced complications, comparable with the literature. We reported multiple types of postoperative complications, including several low morbidity complications such as diarrhea, vertigo, cardiac arrhythmia, remarkable pain and vomiting. All complications are important when surgery is being performed in a healthy individual and does not provide any direct therapeutic advantage. The main focus of living donation is to protect donor safety and minimize the risk of potential complications. Although there are no ideal criteria for safe living liver donation, it is agreed that donors must be between 20 and 50 years of age, have a BMl $<30 \mathrm{~kg} / \mathrm{m}^{2}$, have no evidence of liver steatosis or chronic disease, and have a remnant liver volume of $>30 \%$. In addition, remnant liver weight to donor body weight ratio must be over $0.5 \%$ (15). However, most transplant centers accept donors who do not meet all these criteria depending on the recipient's health situation and deceased donor possibility $(23,24)$. As with our center, many centers utilize living 
liver grafts from donors older than 50 years of age. We know that liver regeneration capacity decreases in older patients, and related to that, the effect of donor age on donor and recipient outcomes after LDLT remains unclear $(15,25,26)$. In the literature with successful outcomes for both donor and recipient, an LDLT has been reported from 76-year-old female living liver donor to her 75-year-old husband (24). Nine of our donors were between the ages 60 and 65 , and 16 were between the ages of 55 and 59 . According to our experience, the complication rate was slightly higher (22.2\%) in donors between the ages of 60 and 65 , which is comparable to the literature (Table 3). With different age cutoffs, different results have been reported in the literature, and it has been concluded that age factor should never be considered as an isolated exclusion criteria for LLDH $(23,24,27)$. Also, twelve of our donors had a BMI $>35 \mathrm{~kg} / \mathrm{m} 2$, and complication rate was $16.7 \%$ in these donors (Table 3). Although overall complication rate was not higher in our high $\mathrm{BMI}\left(>30 \mathrm{~kg} / \mathrm{m}^{2}\right)$ donors, the rate of $P E$, which is a major life-threatening complication, was higher. PE is one of the most important causes of death in the literature. It is important to eliminate predisposing factors. Early mobilization, $\mathrm{LMWH}$ and preoperative embolism stockings were important to decrease the risk of PE $(8,12,14,28)$. Donors older than 60 years of age and donors with a BMl of $>30 \mathrm{~kg} / \mathrm{m}^{2}$ should be evaluated if there is not a better candidate. Recipient physical condition is also an important part of the discussion.

Intra-abdominal bleeding is an important life-threatening complication. Operative bleeding should be carefully managed, which is dependent on the experience and skills of the surgeon. Early recognition of postoperative bleeding and early laparotomy if required are very important, as bleeding may be a serious life-threatening complication (16). Twelve (1.3\%) of our donors experienced perioperative bleeding. Twenty-one (2.4\%) of our donors experienced biliary complications. The literature reports a biliary complication rate of $4 \%$ to $9 \%$ during $\operatorname{LLDH}(14,29,30)$. Gorgan A et al. from the Toronto group have reported a less than $2 \%$ bile leak rate in their donors and explained this slightly lower rate than that in previous series by their approach to not drain the abdominal cavity routinely and some subclinical leaks resolving uneventfully (9).

We did not experience any donor deaths, but we performed DDLT to one of our donors. Even though donor LT was not performed due to a complication of LLDH, after this unfortunate experience, we believe that performing genetic testing in donor candidates who are close relatives of a recipient with hereditary diseases is mandatory during the evaluation. LT after LLDH, due to these complications, has previously been reported in the literature and liver failure after LLDH is the main reason for LT with portal vein thrombosis $(12,16)$. Portal vein variations can make both donor and recipient surgery technically challenging and can increase donor risk. The portal vein closure technique and the fixation of the left lobe to the abdominal wall in right hepatectomy donors are important to prevent PVT. We always fix the left lobe by suturing the falciform ligament to the anterior abdominal wall after right donor hepatectomy to prevent the rotation of the left lobe, a potential cause of PVT. In addition, the rate of biliary system variations is higher in donors with portal vein variations, which also increases risk of biliary complication for both donor and recipient (15).

Since the donor is healthy, the safety of the donor is of paramount importance. In addition, minimally invasive approaches are important for functional and cosmetic demands of the donors. Minimizing the incision is an alternative, which has been reported in the literature with same outcomes (9,31). Beginning with donor left lateral sector hepatectomy in 2002 by Cherqui et al. (32), laparoscopic and other minimally invasive approaches are being used today. This seems feasible and safe when performed by a surgeon who is highly experienced in both laparoscopic and hepatobiliary surgery and with an experienced transplant team (33-35).

The use of living donors with previous abdominal surgery may be a surgical issue which challenges the safety of these altruistic donors. There are few studies which have evaluated the impact of previous abdominal surgery on LLDH with the conclusion that previous abdominal surgery cannot be an absolute contraindication to LLDH in the hands of expert surgeons armed with advanced surgical techniques and maximal care (36). We performed LLDH in several donors who had undergone previous cholecystectomy, appendectomy and caesarean section. No serious complication occurred in these donors due to previous surgery.

Though donors were informed about postoperative pain, onethird of them reported that post-procedure pain was greater than anticipated in the immediate postoperative period (37). Our clinical experience also matches up with this. Eight of our donors reported pain as their main problem, without any other complications during the first days after the procedure. Studies have shown that most donors return to their job after a mean duration of 3 to 4 months, and most donors report that they would donate again if necessary (37-39). We focused on the psychosocial effects of the donation with the limited number of donors in our previous reports (40-42), and a clinical study is currently under way at our center which focuses on these questions.

Although LDLT has helped to resolve the problems of many patients, donors themselves gain no medical benefits, but incur the risks of surgical complications, sometimes with negative psychosocial consequences. Reports have shown that $40 \%$ of the living liver donors report psychological distress after surgery $(12,37,43-45)$. Our experience shows that donor complications and negative recipient outcomes are major causes of psychological distress. In three of our donors, serious anxiety occurred during the first days after the operation and was treated with psychiatrist support. During long-term follow up, we became 
aware of at least two of our donors treated for serious depression. Cheah YL et al's worldwide survey has reported that five donor deaths (21.7\%) were due to suicide between 2 months and 5 years after donation (12). In addition, the literature suggests long-term monitoring of the mental health of living donors to minimize adverse psychosocial outcomes associated with living liver donation (12,43). Preoperative psychosocial evaluation is very important to avoid negative postoperative psychosocial consequences.

For young female donors, pregnancy is one of the concerns in the years following donation. None of our donors who became pregnant after donation reported a bad experience or a complication due to the living liver donation procedure. We suggest female donors that they wait one year after the procedure to become pregnant.

\section{CONCLUSION}

LDLT has become a well-tolerated and safe option when DDLT is not an option. All donors want to save a loved one's life, but the risk of donor morbidity and mortality is a major concern. Surgeon and center experience and higher annual case volume are associated with lower rates of postoperative complications, but LLDH is not a complication-free procedure. All donor candidates should be well informed not only about the details of the early and late risks of living liver donation, but also about possible outcomes for the recipient. In addition to detailed physical evaluation, preoperative psychosocial evaluation is also mandatory. Comprehensive donor evaluation, surgical experience, surgical technique, and close postoperative follow-up and the establishment of a good dialogue with the donor should allow for better outcomes.

Ethics Committee Approval: Authors declared that the research was conducted according to the principles of the World Medical Association Declaration of Helsinki "Ethical Principles for Medical Research Involving Human Subjects" (amended in October 2013). Authors declared that the content of this manuscript complies with all the rules of the "Call for an end to unethical transplant practices" by The Transplantation Society (Transplantation.2019 Apr;103(4):647.) and The Declaration of Istanbul on Organ Trafficking and Transplant Tourism (Transplantation. 2008 Oct ;86(8):1013-8.).

Informed Consent: Written informed consent was obtained from patients who participated in this study.

Peer-review: Externally peer-reviewed.

Author Contributions: Concept - Y.Y.; Design - Y.Y., K.A.; Supervision - Y.Y., K.A.; Resource - Y.Y., M.K., K.A.; Materials Y.Y., M.K., K.A.; Data Collection and/ or Processing - Y.Y., N.M.; Analysis and/or Interpretation - Y.Y., T.K.; Literature Search Y.Y.; Writing Manuscript - Y.Y.; Critical Reviews - T.K., M.K., K.A.

Conflict of Interest: The authors have no conflicts of interest to declare.

Financial Disclosure: The authors declared that this study has received no financial support.

\section{REFERENCES}

1. Ohe H, Hoshino J, Ozawa M. Factors affecting outcomes of liver transplantation: an analysis of OPTN/UNOS database. Clin Transpl 2011: 39-53. PubMed PMID: 22755400. Epub 2011/01/01. [CrossRef]

2. Smith B. Segmental liver transplantation from a living donor.J Pediatr Surg 1969; 4 (1): 126-32. PubMed PMID: 4976215. Epub 1969/02/01. [CrossRef]

3. Raia S, Nery JR, Mies S. Liver transplantation from live donors. Lancet 1989; 2 (8661): 497. PubMed PMID: 2570198. Epub 1989/08/26. [CrossRef]

4. Strong RW, Lynch SV, Ong TH, Matsunami H, Koido Y, Balderson GA. Successful liver transplantation from a living donor to her son. N Engl J Med 1990; 322 (21): 1505-7. PubMed PMID: 2336076. Epub 1990/05/24. [CrossRef]

5. Nydam TL, Reddy MS, Pomfret EA, Rela M. Progression of living liver donation worldwide. Curr Opin Organ Transplant 2018; 23 (2): 162-8. PubMed PMID: 29432257. Epub 2018/02/13. [CrossRef]

6. Dindo D, Demartines N, Clavien PA. Classification of surgical complications: a new proposal with evaluation in a cohort of 6336 patients and results of a survey. Ann Surg 2004; 240 (2): 205-13. PubMed PMID: 15273542. Pubmed Central PMCID: PMC1360123. Epub 2004/07/27. [CrossRef]

7. Broering DC, Wilms C, Bok P, Fischer L, Mueller L, Hillert C, et al. Evolution of donor morbidity in living related liver transplantation: a single-center analysis of 165 cases. Ann Surg 2004; 240 (6): 1013-24. PubMed PMID: 15570207. Pubmed Central PMCID: PMC1356517. Epub 2004/12/01. [CrossRef]

8. Ozbilgin M, Unek T, Egeli T, Agalar C, Ozkardesler S, Karadeniz E, et al. Complications in donors using right liver graft: analysis of 280 consecutive cases. Transplant Proc 2017; 49 (3): 580-6. PubMed PMID: 28340837. Epub 2017/03/28. [CrossRef]

9. Gorgen A, Goldaracena N, Zhang W, Rosales R, Ghanekar A, Lilly L, et al. Surgical complications after right hepatectomy for live liver donation: largest single-center western world experience. Semin Liver Dis 2018; 38 (2): 134-44. PubMed PMID: 29566408. Epub 2018/03/23. [CrossRef]

10. Trotter JF, Adam R, Lo CM, Kenison J. Documented deaths of hepatic lobe donors for living donor liver transplantation. Liver Transpl 2006; 12 (10): 1485-8. PubMed PMID: 16952175. Epub 2006/09/05. [CrossRef]

11. Ozsoy M, Unalp OV, Sozbilen M, Alper M, Kilic M, Zeytunlu M. Results of surgery-related complications in donors of right lobe liver graft: analysis of 272 cases. Transplant Proc 2014; 46 (5): 1377-83. PubMed PMID: 24828563. Epub 2014/05/16. [CrossRef]

12. Cheah YL, Simpson MA, Pomposelli JJ, Pomfret EA. Incidence of death and potentially life-threatening near-miss events in living donor hepatic lobectomy: a world-wide survey. Liver Transpl 2013; 19 (5): 499506. PubMed PMID: 23172840. Epub 2012/11/23. [CrossRef]

13. Middleton PF, Duffield M, Lynch SV, Padbury RT, House T, Stanton P, et al. Living donor liver transplantation--adult donor outcomes: a systematic review. Liver Transpl 2006; 12 (1): 24-30. PubMed PMID: 16498709. Epub 2006/02/25. [CrossRef]

14. Sevmis S, Karakayali H, Karakayali F, Savas NA, Akkoc H, Haberal M. Postsurgical complications in living-related liver donors. Transplant Proc 2008; 40 (1): 245-7. PubMed PMID: 18261598. Epub 2008/02/12. [CrossRef]

15. Guler N, Yaprak O, Gunay Y, Dayangac M, Akyildiz M, Yuzer F, et al. Major complications of adult right lobe living liver donors. Hepatobiliary Pancreat Dis Int 2015; 14 (2): 150-6. PubMed PMID: 25865687. Epub 2015/04/14. [CrossRef] 
16. Onur A, Akbulut S, Dirican A, Isik B, Yilmaz S. Life-threatening or nearly life-threatening complications in living liver donors. Clin Transplant 2018; 32 (6): e13262. PubMed PMID: 29665076. Epub 2018/04/18. [CrossRef]

17. Berglund D, Kirchner V, Pruett T, Mangalick S, Kandaswamy R, Serrano OK, et al. Complications after living donor hepatectomy: analysis of 176 cases at a single center. J Am Coll Surg 2018; 227 (1): 24-36. PubMed PMID: 29555562. Epub 2018/03/21. [CrossRef]

18. Lauterio A, Di Sandro S, Gruttadauria S, Spada M, Di Benedetto F, Baccarani $U$, et al. Donor safety in living donor liver donation: an Italian multicenter survey. Liver Transpl 2017; 23 (2): 184-93. PubMed PMID: 27712040. Epub 2016/10/07. [CrossRef]

19. Lee JG, Lee KW, Kwon CHD, Chu CW, Kim BW, Choi DL, et al. Donor safety in living donor liver transplantation: the Korean organ transplantation registry study. Liver Transpl 2017; 23 (8): 999-1006. PubMed PMID: 28431203. Epub 2017/04/22. [CrossRef]

20. Yankol Y, Mecit N, Kanmaz T, Cimsit B, Cakaloglu Y, Acarli K, et al. Lessons learned from review of a single center experience with 500 consecutive liver transplants in a region with insufficient deceased-donor support. Exp Clin Transplant 2016; 14 (2): 191-200. PubMed PMID: 26030810. Epub 2015/06/02. [CrossRef]

21. Abecassis MM, Fisher RA, Olthoff KM, Freise CE, Rodrigo DR, Samstein $B$, et al. Complications of living donor hepatic lobectomy--a comprehensive report. Am J Transplant 2012; 12 (5): 1208-17. PubMed PMID: 22335782. Pubmed Central PMCID: PMC3732171. Epub 2012/02/18. [CrossRef]

22. Suh KS, Suh SW, Lee JM, Choi Y, Yi NJ, Lee KW. Recent advancements in and views on the donor operation in living donor liver transplantation: a single-center study of 886 patients over 13 years. Liver Transpl 2015; 21 (3): 329-38. PubMed PMID: 25488794. Epub 2014/12/10. [CrossRef]

23. Kim SH, Lee EC, Shim JR, Park SJ. Right lobe living donors ages 55 years old and older in liver transplantation. Liver Transpl 2017;23 (10): 130511. PubMed PMID: 28734130. Epub 2017/07/25. [CrossRef]

24. Dayangac M, Taner CB, Yaprak O, Demirbas T, Balci D, Duran C, et al. Utilization of elderly donors in living donor liver transplantation: when more is less? Liver Transpl 2011; 17 (5): 548-55. PubMed PMID: 21506243. Epub 2011/04/21. [CrossRef]

25. Kuramitsu K, Egawa H, Keeffe EB, Kasahara M, Ito T, Sakamoto S, et al. Impact of age older than 60 years in living donor liver transplantation. Transplantation 2007; 84 (2): 166-72. PubMed PMID: 17667807. Epub 2007/08/02. [CrossRef]

26. Olthoff KM. Hepatic regeneration in living donor liver transplantation. Liver Transpl 2003; 9 (10 Suppl 2): S35-41. PubMed PMID: 14528426. Epub 2003/10/07. [CrossRef]

27. Hoon Kim S, Duke Lee S, Kyu-Kim Y, Park SJ. Living donors ages 60 or older in right lobe living donor liver transplantation. Transplantation 2015; 99 (3): e16-7. PubMed PMID: 25695789. Epub 2015/02/20. [CrossRef]

28. Renz JF, Roberts JP. Long-term complications of living donor liver transplantation. Liver Transpl 2000; 6 (6 Suppl 2): S73-6. PubMed PMID: 11084090. Epub 2000/11/21. [CrossRef]

29. Tanemura A, Mizuno S, Hayasaki A, Fujii T, lizawa Y, Kato H, et al. Biliary complications during and after donor hepatectomy in living donor liver transplantation focusing on characteristics of biliary leakage and treatment for intraoperative bile duct injury. Transplant Proc 2018; 50 (9): 2705-10. PubMed PMID: 30401381. Epub 2018/11/08. [CrossRef]

30. Braun HJ, Ascher NL, Roll GR, Roberts JP. Biliary complications following living donor hepatectomy. Transplant Rev (Orlando) 2016; 30 (4): 247-52. PubMed PMID: 27531698. Epub 2016/08/18. [CrossRef]
31. Demirbas T, Bulutcu F, Dayangac M, Yaprak O, Guler N, Oklu L, et al. Which incision is better for living-donor right hepatectomy? Midline, J-shaped, or Mercedes. Transplant Proc 2013; 45 (1): 218-21. PubMed PMID: 23375303. Epub 2013/02/05. [CrossRef]

32. Cherqui D, Soubrane O, Husson E, Barshasz E, Vignaux O, Ghimouz M, et al. Laparoscopic living donor hepatectomy for liver transplantation in children. Lancet 2002; 359 (9304): 392-6. PubMed PMID: 11844509. Epub 2002/02/15. [CrossRef]

33. Lee KW, Hong SK, Suh KS, Kim HS, Ahn SW, Yoon KC, et al. One hundred fifteen cases of pure laparoscopic living donor right hepatectomy at a single center. Transplantation 2018; 102 (11): 1878-84. PubMed PMID: 29684001. Epub 2018/04/24. [CrossRef]

34. Chen KH, Siow TF, Chio UC, Wu JM, Jeng KS. Laparoscopic donor hepatectomy. Asian J Endosc Surg 2018; 11 (2): 112-7. PubMed PMID: 29869841. Epub 2018/06/06. [CrossRef]

35. Suh KS, Hong SK, Lee KW, Yi NJ, Kim HS, Ahn SW, et al. Pure laparoscopic living donor hepatectomy: focus on 55 donors undergoing right hepatectomy. Am J Transplant 2018; 18 (2): 434-43. PubMed PMID: 28787763. Epub 2017/08/09. [CrossRef]

36. Kim SH, Lee SD, Kim YK, Park SJ. Right hepatectomy in living donors with previous abdominal surgery. Hepatobiliary Pancreat Dis Int 2017; 16 (1): 33-8. PubMed PMID: 28119256. Epub 2017/01/26. [CrossRef]

37. Wang SH, Lin PY, Wang JY, Huang MF, Lin HC, Hsieh CE, et al. Mental health status after living donor hepatectomy. Medicine (Baltimore) 2017; 96 (19): e6910. PubMed PMID: 28489808. Pubmed Central PMCID: PMC5428642. Epub 2017/05/11. [CrossRef]

38. Sevmis S, Diken T, Boyvat F, Torgay A, Haberal M. Right hepatic lobe donation: impact on donor quality of life. Transplant Proc 2007; 39 (4): 826-8. PubMed PMID: 17524824. Epub 2007/05/26. [CrossRef]

39. Parolin MB, Lazzaretti CT, Lima JH, Freitas AC, Matias JE, Coelho $J C$. Donor quality of life after living donor liver transplantation. Transplant Proc 2004; 36 (4): 912-3. PubMed PMID: 15194313. Epub 2004/06/15. [CrossRef]

40. Tankurt A, Krespi Boothby MR, Acarli K, Kalayoglu M, Kanmaz T, Yankol Y. Liver transplantation: recipients' evaluation of life from the perspective of living donors. Transplant Proc 2016; 48 (1): 107-10. PubMed PMID: 26915852. Epub 2016/02/27. [CrossRef]

41. Krespi MR, Tankurt A, Acarli K, Yankol Y, Kalayoglu M, Kanmaz T. Postdonation evaluation of life of donors of liver transplantation. Cogent Psychol 2016; 3. PubMed PMID: WOS:000391512900001. [CrossRef]

42. Krespi MR, Tankurt A, Acarli K, Kanmaz T, Yankol Y, Kalayoglu M. Beliefs of living donors about recipients' end-stage liver failure and surgery for organ donation. Transplant Proc 2017; 49 (6): 1369-75. PubMed PMID: 28736009. Epub 2017/07/25. [CrossRef]

43. Dew MA, Butt Z, Humar A, DiMartini AF. Long-term medical and psychosocial outcomes in living liver donors. Am J Transplant 2017; 17 (4): 880-92. PubMed PMID: 27862972. Pubmed Central PMCID: PMC5510163. Epub 2016/11/20. [CrossRef]

44. Lauterio A, Poli C, Cusumano C, Di Sandro S, Tripepi M, Mangoni I, et al. Living-donor liver transplantation: donor selection criteria and postoperative outcomes. A single-center experience with a 10year follow-up. Transplant Proc 2013; 45 (7): 2680-3. PubMed PMID: 24034023. Epub 2013/09/17. [CrossRef]

45. Ozgor D, Dirican A, Ates M, Gonultas F, Ara C, Yilmaz S. Donor complications among 500 living donor liver transplantations at a single center. Transplant Proc 2012; 44 (6): 1604-7. PubMed PMID: 22841225. Epub 2012/07/31. [CrossRef] 


\title{
ORIJINAL ÇALIŞMA-ÖZET
}

Turk J Surg 2020; 36 (2): 192-201

\section{Tek merkezde gerçekleştirilmiş 890 canlı karaciğer donör hepatektomisinin komplikasyonları ve sonuçları: sevdiğin birinin hayatını kurtarmanın riskleri}

\author{
Yücel Yankol ${ }^{1,2}$, Nesimi Mecit ${ }^{1,3}$, Turan Kanmaz ${ }^{1,3}$, Münci Kalayoğlu ${ }^{1,3}$, Koray Acarlı $^{1}$ \\ ${ }^{1}$ Memorial Şişli Hastanesi, Organ Nakli Merkezi, İstanbul, Türkiye \\ ${ }^{2}$ Wisconsin Üniversitesi, Cerrahi Anabilim Dalı, Organ Nakli Bölümü, Madison, WI, Amerika Birleşik Devletleri \\ ${ }^{3}$ Koç Üniversitesi Tıp Fakültesi Hastanesi, Organ Nakli Merkezi, İstanbul, Türkiye
}

\section{ÖZET}

Giriş ve Amaç: Canlı karaciğer verici ameliyatı tamamen sağlıklı bireylere uygulanan, vericinin doğrudan terapötik bir kazanç elde etmediği, ölüm ve ciddi komplikasyon riskleri taşıyan büyük bir cerrahi işlemdir. Bu çalışmamızda; canlı karaciğer vericisi olmanın riskini ortaya koymak amacıyla retrospektif olarak canlı karaciğer verici ameliyatı geçirmiş vericilerimizin ameliyat sonrası komplikasyonlarını ve sonuçlarını inceledik.

Gereç ve Yöntem: Kasım 2006-Aralık 2018 tarihleri arasında merkezimizde alıcısı ile yakınlık ilişkisi bulunan toplam 939 karaciğer vericisine, canlı karaciğer verici hepatektomisi mortalitesiz olarak gerçekleştirildi. Bu olgulardan minimum bir yıl takipli 890'ı retrospektif olarak incelendi.

Bulgular: İncelen 890 vericiden, 519 (\%58,3)'u erkek, 371 (\%41,7)'i kadındı. Ortalama yaş 35 (18-64) ve ortalama beden kütle indeksi 25,7 kg/m2 (17.7-40) idi. Canlı sağ verici hepatektomisi $601(\% 67,5)$, sol verici hepatektomisi $28(\% 3,2)$ ve verici sol lateral sektör hepatektomisi $261(\% 29,3)$ vericide gerçekleştirilmiştir. Vericilerden 174 (\%19,5)'ünde toplam 204 komplikasyon görülmüştür. Bunların 26 (\%2,9)'sında hayatı tehdit edici komplikasyonlar gelişmiştir. Cerrahi işlem sırasında $4(\% 0,5)$ vericide komplikasyon gelişmiştir. Canlı sağ verici hepatektomisinde $(\% 23,3)$ komplikasyon oranları, sol $(14,3 \%)$ ve sol lateral sektör hepatektomisine $(\% 11,5)$ göre daha fazla gözlenmiştir.

Sonuç: Tüm verici adayları sadece verici ameliyatının detayları, erken ve geç komplikasyonları ile ilgili olarak değil ayrıca alıcının olası sonuçları hakkında da ayrıntılı olarak bilgilendirilmelidir. Ayrıntılı klinik muayene, tetkik ve değerlendirmelere ek olarak psiko-sosyal değerlendirme de kaçınılmazdır. Kapsamlı verici değerlendirilmesi, cerrahi deneyim ve teknik, yakın cerrahi sonrası takip, verici ve yakınları ile kurulacak iyi diyalog daha iyi sonuçları elde etmemizi sağlayacaktır.

Anahtar Kelimeler: Canlı verici hepatektomisi, komplikasyon, sonuç, canlı vericili karaciğer nakli, hayat tehdit edici komplikasyon

Doi: $10.5578 /$ turkjsurg.4548 